\title{
Influence of Annealing on Pt Electrocatalyst: Theoretical Approach to Estimate CO Tolerance
}

\author{
Andrey Tokarev, and Dmitri Bessarabov \\ Hydrogen Infrastructure Center of Competence (HySA Infrastructure), North-West University, Faculty \\ of Engineering, Private Bag X6001, Potchefstroom, 2520 South Africa \\ *E-mail: Dmitri.Bessarabov@nwu.ac.za
}

doi: $10.20964 / 1104311$

Received: 31 January 2016 / Accepted: 7 March 2016 / Published: 1 April 2016

For electrocatalytic energy hydrogen systems such as fuel cell (FC) and hydrogen compression there is a demanding requirement for the hydrogen purity. There is a vast opportunity to produce hydrogen from various sources, including fossil fuels; however, in many cases such hydrogen will contain various impurities, such as CO. In our previous work we showed that annealing of a catalyst affects its $\mathrm{CO}$ tolerance. Using the same theoretical model for investigating $\mathrm{CO}$ tolerance of a catalyst, we explored how temperature of annealing affects $\mathrm{CO}$ poisoning of a platinum whiskerette, a nanoobject of an extended-surface support, such as $3 \mathrm{M}$ nanostructured thin film (NSTF), or other structures produced by, for example, glancing angle deposition (GLAD) methods, etc. Here we present results of molecular dynamic (MD) modeling of the whiskerette as a model of extended structure annealed at temperatures from 400 to $1200 \mathrm{~K}$. We found that $\mathrm{CO}$ coverage increases with annealing temperature, that is, at high temperatures there are more deformations which lead to high $\mathrm{CO}$ coverage. Interestingly, we observed sharp peak of CO coverage at temperature above $1000 \mathrm{~K}$. Obtained results suggest range of optimal annealing temperatures.

Keywords: CO tolerance, extended-surface support, annealing, molecular dynamics

\section{$\underline{\text { FULL TEXT }}$}

(C) 2016 The Authors. Published by ESG (www.electrochemsci.org). This article is an open access article distributed under the terms and conditions of the Creative Commons Attribution license (http://creativecommons.org/licenses/by/4.0/). 